\title{
ANALISIS PERSEDIAAN BERAS PADA PERUSAHAAN UMUM BULOG DIVISI REGIONAL JAWA TIMUR
}

\section{(Inventory Analysis of Rice at BULOG Regional Division of East Java)}

\author{
E.Y.D. Kristyaningrum, T. Ekowati dan A. Setiadi \\ Program Studi S1 Agribisnis Fakultas Peternakan dan Pertanian \\ Universitas Diponegoro, Kampus Tembalang, Semarang 50275 \\ Email :evaydk87@gmail.com \\ Diterima 7 Februari 2017, disetujui 1 Maret 2017
}

\begin{abstract}
ABSTRAK
Bahan pangan pokok masyarakat Indonesia adalah beras. Perum BULOG memiliki tugas Public Service Obligation untuk menjaga ketersediaan beras di Indonesia. Tujuan penelitian ini adalah 1) menganalisis jumlah pemesanan beras yang ekonomis pada setiap kali pemesanan oleh Perum BULOG Divisi Regional Jawa Timur Tahun 2011-2015; 2) menganalisis kinerjamanajemen persediaan beras oleh Perum BULOG Divisi Regional Jawa Timur. Metode penelitian ini adalah studi kasus. Penentuan lokasi menggunakan metode purposive sampling. Nilai EOQ di Perum BULOG Divre Jawa Timur Tahun 2011-2015 berturut-turut sebesar 3.218 ton; 3.983 ton; 3.860 ton; 2.038 ton; dan 3.331 ton. Kinerja Perum BULOG Divisi Regional Jawa Timur sebagai penyangga kebutuhan gabah beras dalam negeri tergolong baik namun biaya persediaan yang dikeluarkan belum efisien.
\end{abstract}

Kata Kunci : beras, BULOG,Economic Order Quantity, efisien, persediaan

\begin{abstract}
Rice is a main food in Indonesia. Perum BULOG has the duty of Public Service Obligation (PSO) to keep the availability of rice in Indonesia. The objectives of this study were to 1) analyze the economic order quantity at Perum BULOG Regional Division of East Java in 20112015; and 2) to analyze inventory management performance of rice at Perum BULOG Regional Division of East Java. The research method was case study. Purposive sampling was used to determine research location. Research result showed that economic order quantity at Perum BULOG Regional Division of East Java in 2011, 2012, 2013, 2014, 2015 were 3,218 ton; 3,983 ton; 3,860 ton; 2,038 ton; and 3,331 tonrespectively. Forecasting result of economic order quantity at Perum BULOG Regional Division of East Java in 2016, 2017, 2018, 2019, 2020 were 2,770.5 ton; 2,598.6 ton; 2,426.7 ton; 2,254.8 ton; 2,082.9 tonrespectively. Inventory management performance by Perum BULOG Regional Division of East Java as a buffer requirement of domestic rice and grain was good but the inventory cost has not been efficientyet.
\end{abstract}

Keywords: BULOG, Economic Order Quantity, efficient, inventory,rice 


\section{PENDAHULUAN}

Padi adalah bahan pangan pokok yang memenuhi kebutuhan gizi mayoritas masyarakat diberbagai negara seperti di kawasan Asia, Amerika Latin, Karibia, dan Afrika (Singh dan Hensel, 2012). Beras merupakan bahan pangan pokok masyarakat Indonesia, sehingga beras menguasai hajat hidup orang banyak serta menjadi parameter stabilitas ekonomi dan sosial negara (Bulog, 2012). Laju pertumbuhan penduduk di Indonesia pada tahun 2000-2015 mencapai angka 1,4 (BPS, 2015). Pertumbuhan penduduk yang terus meningkat menyebabkan kebutuhan beras juga meningkat. Ketersediaaan beras diharapkan terus menjamin kebutuhan beras. Badan Urusan Logistik (BULOG) memiliki tugas Public Service Obligation (PSO) dengan menjaga harga dasar pembelian untuk gabah, stabilisasi harga khususnya harga pokok, menyalurkan beras untuk orang miskin (Raskin) dan pengelolaan persediaan pangan. Pelaksanaan tugas PSO diharapkan mampu menjaga ketersediaan dan keterjangkauan beras bagi masyarakat.Visi BULOG adalah menjadi perusahaan yang unggul dalam mewujudkan kedaulatan pangan. Visi tersebut diwujudkan dalam beberapa misi antara lain memberikan pelayanan prima kepada masyarakat dan pemangku kepentingan lainnya untuk memenuhi kebutuhan pangan pokok; mencapai pertumbuhan usaha yang berkelanjutan; dan menerapkan tata kelola perusahaan yang baik.

Manajemen persediaan beras dilakukan dengan mengetahui alur pengadaan beras, saluran pengadaan beras, pengadaan beras, perawatan kualitas beras, dan pengeluaran beras.Ketersediaan beras yang kontinyu merupakan indikator keberhasilan manajemen persediaan beras di Perum BULOG. Manajemen persediaan yang baik diperoleh bila nilai pengadaan mencapai titik ekonomis dimana ketersediaan selalu mencukupi kebutuhan dan biaya yang dikeluarkan efisien. Titik ekonomis dapat dihitung menggunakan analisis economic order quantity (EOQ). Perum BULOG Divisi Regional Jawa Timur adalah satu-satunya lembaga yang mengelola ketersediaan beras di Jawa Timur. Perum BULOG Divisi Regional Jawa Timur merupakan Perum BULOG terbesar di Indonesia karena mampu memenuhi kebutuhan beras bukan hanya di wilayah Jawa Timur namun di seluruh Indonesia. Berdasarkan latar belakang, penelitian ini dilakukan untuk menganalisis jumlah pesanan beras ekonomis di Perum BULOG Divisi Regional Jawa Timur menggunakan rumus EOQ.

Tujuan penelitian ini adalah :

1. Menganalisis jumlah pesanan beras yang ekonomis pada setiap kali pemesanan oleh Perum BULOG Divisi Regional Jawa Timur Tahun 2011-2015 menggunakan metode EOQ

2.Menganalisis kinerja manajemen persediaan beras oleh Perum BULOG Divisi Regional Jawa Timur.

\section{METODE PENELITIAN}

Studi kasus merupakan metode penelitian ini yang terfokus pada suatu kasus tertentu untuk dianalisis secara tuntas. Kasus dalam penelitian ini adalah jumlah pesanan beras ekonomis dan pelaksanaan manajemen persediaan di Perum BULOG Divisi Regional Jawa Timur.

\section{Metode Penentuan Lokasi}

Waktu pelaksanaan penelitian pada Bulan September sampai November 2016. Lokasi penelitian di Perum BULOG Divisi Regional Jawa Timur, Jalan Jend. Ahmad Yani 146-148, Surabaya. Metode purposive sampling dilakukan untuk menentukan lokasi dengan alasan Perum BULOG Divisi Regional Jawa Timur adalah satu-satunya lembaga yang mengelola ketersediaan beras di Jawa Timur.

\section{Metode Pengumpulan Data}

Data yang perlu dikumpulkan adalah data primer dan data sekunder. Pengumpulan data primer dilakukan dengan cara melakukan wawancara kepada informan kunci dengan mengajukan berbagai jenis pertanyaan yang 
telah dipersiapkan sebelumnya. Informan kunci data primer adalah Ketua Seksi Persediaan dan Angkutan, Ketua Seksi Pengadaan, Ketua Seksi Penyaluran, Ketua Seksi Perawatan Kualitas dan beberapa staff masing-masing seksi tersebut.

Data sekunder diperoleh dari observasi, studi pustaka, dan pencatatan data yang berkaitan dengan jumlah pesanan beras ekonomis seperti data pengadaan beras dan data penyaluran beras. Data yang telah diperoleh diolah dan dianalisis sehingga menjadi dasar pembahasan pada penyusunan laporan. Hasil pengolahan data dibandingkan dengan berbagai pustaka, kemudian dilakukan penyusunan hasil penelitian.

\section{Metode Analisis Data}

Metode deskriptif dan metode kuantitatif digunakan untuk menganalisis data. Metode deskriptif bertujuan untuk menggambarkan sifat suatu keadaan saat penelitian dilakukan dan memeriksa sebab-sebab dari suatu kondisi tertentu. Metode ini digunakan untuk menjawab tujuan. Metode kuantitatif adalah metode perhitungan yang digunakan untuk menyatakan kesimpulan yang dibuktikan dengan angka. Tujuan 1 dianalisis dengan rumus EOQ.

Analisis EOQ digunakan untuk menghitung jumlah pesanan beras yang ekonomis dalam setiap pemesanan. Asumsiasumsi yang perlu diketahui menurut Petty dan Scott (2005) yaitu biaya pemesanan setiap kali pesan tetap, harga pembelian beras tetap, biaya penyimpanan tetap, dan beras selalu tersedia di pasar. Asumsi tersebut dapat berubah sewaktu-waktu sesuai kondisi perusahaan yang akan diteliti.

$\mathrm{EOQ}=\sqrt{ }(2 \mathrm{AP} / \mathrm{RC})$

Keterangan:

EOQ $=$ Jumlah pesanan beras ekonomissetiap pemesanan (ton)

$\mathrm{A}=$ Kebutuhan beras per tahun (ton)

$\mathrm{P}=$ Biaya pemesanan beras setiap kali pesan (Rp)

$\mathrm{R}=$ Harga beras per ton $(\mathrm{Rp})$

$\mathrm{C}$ = Biaya penyimpanan beras dari biaya pembelian yang dinyatakan dalam persentase $(\%)$

\section{HASIL DAN PEMBAHASAN}

\section{Manajemen Persediaan Beras}

Manajemen persediaan beras di Perum BULOG Divisi Regional Jawa Timur diawali dari alur pengadaan beras, pengadaan beras, persediaan beras, perawatan kualitas beras dan penyaluran beras. Wijayanti et al.(2011) mengungkapkan bahwa pengelolaan persediaan penting dilakukan untuk menunjang upaya pemenuhan kebutuhan beras di masyarakat. Alur pengadaan beras berawal dari Kantor Pusat Perum BULOG memberikan target pengadaan kepada Divisi Regional (Divre)/Sub Divisi Regional (Subdivre). Divre/Subdivre melakukan kontrak melalui 3 saluran yaitu Unit Bisnis Pengolahan Gabah dan Beras (UB-PGB), Mitra Kerja, dan Satuan Tugas (SATGAS). Ketiga saluran tersebut mengirimkan beras ke gudang yang ditunjuk, sesuai dengan jumlah yang disepakati. Penerimaan beras di gudang diawali dengan survei pemeriksaan kualitas dan kuantitas sebelum masuk oleh petugas pemeriksa kualitas. Bila kualitas dan kuantitas sesuai dengan kesepakatan maka gudang menerima beras dan membuat laporan penerimaan barang.

Sumber pengadaan beras Perum BULOG Divre Jawa Timur hanya berasal dari dalam negeri. Beras dibeli dari hasil produksi petani di 38 Kabupaten di Jawa Timur. Pengadaan beras Perum BULOG Divre Jawa Timur berdasarkan target yang diberikan oleh Kantor Pusat. Kapasitas maksimun gudang di Perum BULOG Divisi Regional Jawa Timur sebesar 1.139.000 ton, sehingga persediaan beras maksimum di gudang Perum BULOG Divre Jawa Timur sebesar 1.139.000 ton. Pengadaan beras berasal dari pengadaan dalam negeri, hasil giling gabah, hasil reproses/ rebaging, move regional in, move nasional in, pengadaan luar negeri, pengembalian, pembatalan Delivery Order (DO), dan koreksi.

Pegeluaran meliputi penyaluran golongan angkatan (golang) berdasarkan perintah logistik (prinlog), penyaluran golang diluar prinlog, penyaluran raskin, cadangan beras pemerintah, penyaluran lain-lain, 
ekspor, giling gabah, reproses/rebaging, move regional out, move nasional out, kehilangan/kekurangan/pemusnahan, susut simpan, turun mutu, dan koreksi. Penyaluran golang berdasarkan prinlog adalah penyaluran untuk TNI, POLRI, dan Departemen Sosial sesuai dengan surat perintah logistik dari pusat. Penyimpanan beras di gudang Subdivre Surabaya Utara terdiri dari beberapa tumpukan. Satu tumpukan berisi 25 tingkat beras dengan berat bersih $50 \mathrm{~kg}$. Gudang di Divre Jawa Timur menggunakan metode FIFO (First In First Out) artinya persediaan beras yang pertama masuk gudang adalah persediaan pertama yang keluar gudang. Perum BULOG menggunakan metode FIFO dengan harapan kualitas barang tidak menurun saat penyimpanan di gudang. Semakin lama beras disimpan di gudang semakin tinggi potensi kualitas beras menurun. Hal tersebut didukung oleh Raras dan Casper (2011) yang menyatakan bahwa semakin lama masa penyimpanan beras maka kadar pati, protein, dan lemak dalam beras semakin turun.

Pegontrolan beras di gudang dilakukan oleh Seksi Pest Quality Control (PQC) sesuai dengan Standar Operasional Prosedur (SOP) dan administrasi sebelum dilakukan. Perawatan kualitas beras di dalam gudang hanya dengan spraying dan fumigasi. Spraying dilakukan rutin setiap bulan atau pada saat hama masih tingkat rendah. Fumigasi dilakukan 3 bulan sekali oleh Seksi PQC dan tenaga buruh. Hama paling berbahaya di gudang Perum BULOG Divre Jawa Timur adalah hama Rhyzoperta $s p$. karena hama ini dapat mengubah beras menjadi butiran. Hal tersebut didukung oleh Wiranata et al. (2013) yang menyatakan bahwa populasi tertinggi pada gudang BULOG di Kabupaten Jember adalah Rhyzoperta dominica dengan 718 individu sedangkan hama jenis lain hanya berjumlah antara 131-176 individu. Hama tersebut dapat dimusnahkan dengan cara fumigasi.

\section{Economic Order Quantity (EOQ)}

Jumlah pemesanan beras yang ekonomis pada setiap kali pemesanan dapat ditentukan melalui metode EOQ. Metode ini sangat cocok untuk mengatasi masalah persediaan yang berkaitan dengan jumlah pemesanan yang kurang optimal. Hal tersebut didukung oleh Heizer dan Render (2008) yang menyatakan bahwa jumlah pesanan ekonomis atau EOQ adalah salah satu teknik manajemen teknik manajemen persediaan yang meminimalkan biaya total dari pemesanan dan penyimpanan. Metode ini digunakan untuk mengetahui kuantitas pesanan yang ekonomis sehingga meningkatkan keuntungan. Data yang harus tersedia dalam menghitung EOQ menurut Fitriani et al. (2014) adalah kebutuhan beras selama satu tahun, harga beras per ton, biaya pemesanan, dan biaya penyimpanan. Asumsi yang digunakan dalam menghitung EOQ menurut Petty dan Scott (2005) adalah harga pembelian beras tetap, biaya pengadaan tetap, biaya penyimpanan tetap, dan beras selalu tersedia di pasar. Biaya pengadaan diperoleh dari penjumlahan dari

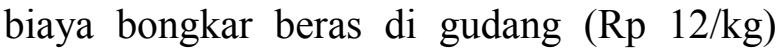
dan biaya survei kualitas di gudang ( $R p$ $3,6 / \mathrm{kg}$ ). Jumlah biaya penga-daan sebesar Rp $15,6 / \mathrm{kg}$. Biaya penyimpanan terdiri dari biaya fumigasi $\mathrm{Rp} 6,34 / \mathrm{kg}$ dan biaya spraying $\mathrm{Rp}$ $322 / \mathrm{m}^{2}$ atau sekitar Rp 7,55/kg sehingga jumlah biaya penyimpanan sebesar Rp 13,89/kg. Hasil pengolahan data disajikan pada Tabel 1.

Nilai EOQ di Perum BULOG Divre Jawa Timur lebih besar bila dibandingkan dengan EOQ di Perum BULOG Divre Nusa Tenggara Timur (NTT). Hasil penelitian Fitriani et al. (2014) menyatakan bahwa EOQ di Perum BULOG Divre NTT pada Tahun 2011 sebesar 816,65 ton. Sedangkan EOQ di Perum BULOG Divre Jawa Timurpada Tahun 2011 sebesar 3.218 ton. Hal tersebut terjadi karena kebutuhan beras di Jawa Timur lebih besar daripada NTT.Selisih nilai EOQ dan realisasi Tahun 2012 sebesar 1.245 ton, sehingga pengadaan beras di Perum BULOG Divre Jawa Timur dapat dikatakan belum optimal. Hal ini senada dengan pendapat Famee (2015) yang menyatakan bahwa kuantitas pengadaan beras Perum BULOG Divre Daerah Istimewa Yogyakarta (DIY) Tahun 2012-2014 belum optimal. Hal ini 
Tabel 1.Kebutuhan, Harga, Biaya Pemesanan, Biaya Penyimpanan Beras dan EOQ di Perum BULOG Divre Jawa Timur pada Tahun 2011-2015

\begin{tabular}{|c|c|c|c|c|c|}
\hline Tahun & $\begin{array}{l}\text { Kebutuhan } \\
\text { beras }\end{array}$ & $\begin{array}{l}\text { Harga beras } \\
\text { per ton }\end{array}$ & $\begin{array}{c}\text { Biaya } \\
\text { pemesanan }\end{array}$ & $\begin{array}{l}\text { Persentase Biaya } \\
\text { penyimpanan dari } \\
\text { Biaya Pengadaan }\end{array}$ & EOQ \\
\hline & -----ton/th---- & \multicolumn{2}{|c|}{-----------------Rp--------------- } & -------\%------ & ---ton--- \\
\hline 2011 & 978.635 & 5.060 .000 & 61.370 .342 & 2,29 & 3.218 \\
\hline 2012 & 1.127 .650 & 6.600 .000 & 81.552 .178 & 1,76 & 3.983 \\
\hline 2013 & 1.151 .314 & 6.600 .000 & 75.048 .480 & 1,76 & 3.860 \\
\hline 2014 & 754.499 & 6.600 .000 & 31.929 .098 & 1,76 & 2.038 \\
\hline 2015 & 1.189 .442 & 7.300 .000 & 54.097 .564 & 1,59 & 3.331 \\
\hline
\end{tabular}

Sumber : Data diolah, 2016

terjadi karena beberapa faktor yaitu masa panen, jumlah beras yang dipanen petani dan jumlah kebutuhan beras.

\section{Analisis Kinerja Manajemen Persediaan Beras}

Analisis kinerja manajemen persediaan beras dilakukan dengan membandingkan target pengadaan dan realisasi pengadaan kemudian membandingkan EOQ dan realisasi pemesanan (Tabel 2).

Berdasarkan Tabel 2 diketahui bahwa nilai realisasi cenderung lebih tinggi dibandingkan target yang ditentukan. Perum BULOG Pusat menyediakan dana pengadaan beras sebesar target yang ditentukan. Oleh karena itu, biaya pengadaan yang dikeluarkan lebih tinggi dari dana yang sudah disiapkan. Sumber modal Perum BULOG berasal dari Anggaran Pendapatan dan Belanja Negara (APBN) dan pendapatan unit bisnis yang dimiliki Perum BULOG. Hal tersebut diketahui berdasarkan Ringkasan Eksekutif Kementrian Keuangan Republik Indonesia tentang Regulasi Penugasan Pemerintah kepada Perum BULOG yang menyatakan bahwa pengadaan dan pengelolaan cadangan beras pemerintah dan beras bersubsidi didanai oleh APBN sebagai cadangan beras nasional beserta penyalurannya sesuai ketentuan Inpres dan PMK. Berdasarkan Peraturan Pemerintah Republik Indonesia Nomor 49 Tahun 2015 diketahui bahwa pemerintah memberikan penambahan penyertaan modal ke dalam modal Perum BULOG sebesar Rp 3.000.000.000.000 yang bersumber dari APBN Tahun Anggaran 2015.

Berdasarkan Grafik 2. dapat diketahui bahwa selisih nilai EOQ dan realisasi pengadaan beras berkisar antara 9 - 1.245 ton. Selisih terbesar terjadi pada Tahun 2012 yaitu 1.245 ton dan selisih terkecil pada Tahun 2014 yaitu 137 ton. Nilai realisasi pemesanan beras melebihi nilai EOQ. Hal tersebut dipengaruhi oleh kebutuhan beras dan produksi petani. Semakin tinggi kebutuhan beras di masyarakat maka realisasi yang dilakukan Perum BULOG pasti melebihi EOQ. Pengadaan beras di Perum BULOG berdasarkan produksi petani artinya berapapun jumlah beras hasil panen yang diproduksi petani, semuanya akan dibeli Perum BULOG. Semakin banyak produksi petani semakin tinggi nilai realisasi.Nilai realisasi pemesanan yang semakin tinggi menyebabkan biaya pengadaan semakin tinggi. Sehingga biaya yang dikeluarkan tidak efisien.

Tabel 2. Target Pengadaan dan Realisasi PengadaanBeras di Perum BULOG Divre Jawa Timur pada Tahun 2011-2015

\begin{tabular}{lrrrrr}
\hline \hline & 2011 & 2012 & 2013 & \multicolumn{1}{c}{2014} & \multicolumn{1}{c}{2015} \\
\hline & --------- \\
Target & 700.000 & 1.036 .350 & 1.100 .000 & 1.100 .000 & 850.000 \\
Realisasi & 1.062 .179 & 1.411 .480 & 1.298 .916 & 552.619 & 936.304 \\
\hline
\end{tabular}

Sumber : Data diolah (2016) 


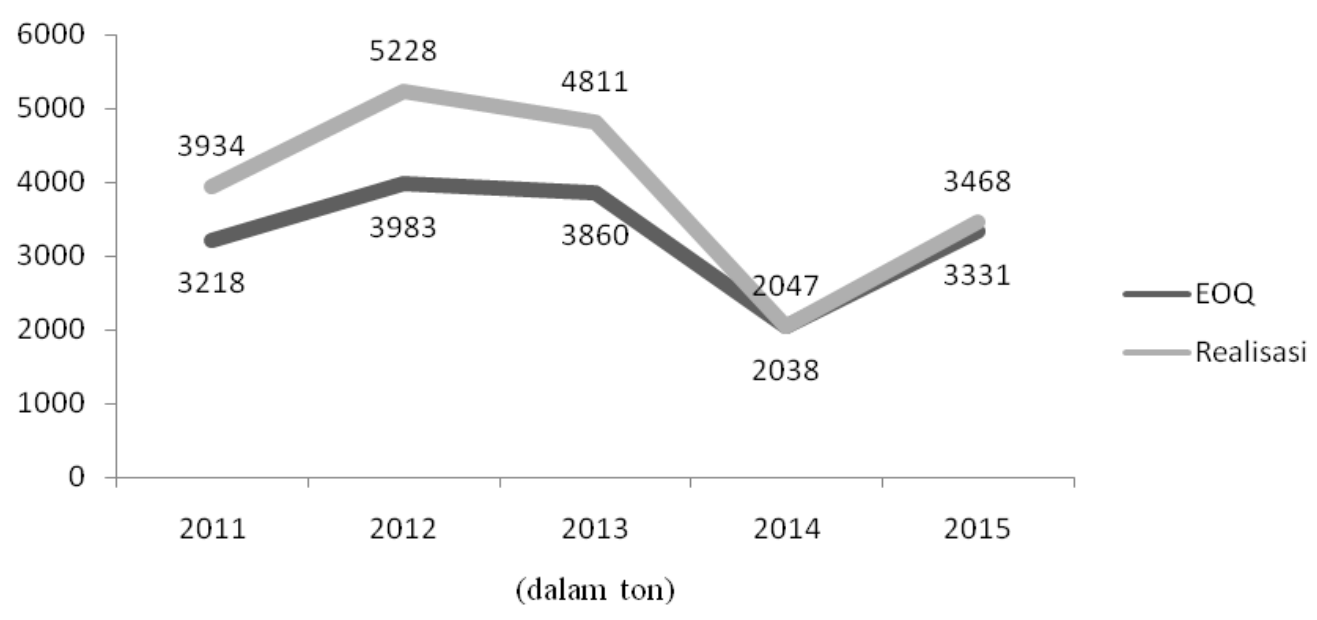

Ilustrasi 1. Perbandingan EOQ dan Realisasi Pemesanan

Berdasarkan perbandingan target pengadaan dan realisasi pengadaan serta perbandingan EOQ dan realisasi pemesanan dapat diketahui bahwa kinerja Perum BULOG Divisi Regional Jawa Timur sebagai penyangga kebutuhan gabah beras dalam negeri tergolong baik karena melebihi target yang ditentukan dan mampu memenuhi kebutuhan beras bukan hanya di wilayah Jawa Timur namun seluruh Indonesia melalui movenas. Kenaikan jumlah pengadaan menyebabkan biaya yang dikeluarkan lebih tinggi sehingga belum efisien. Hal tersebut dapat mempengaruhi misi Perum BULOG yaitu menerapkan tata kelola perusahaan yang baik. Penerapan tata kelola perusahaan yang baik dapat dilakukan dengan menerapkan metode EOQ dalam menentukan jumlah pesanan beras ekonomis sehingga biaya persediaan yang dikeluarkan lebih efisien.

\section{SIMPULAN DAN SARAN}

\section{Simpulan}

Berdasarkan hasil penelitian dan perhitungan dapat disimpulkan bahwa:

1. Nilai EOQ di Perum BULOG Divre Jawa Timur Tahun 2011-2015 berturut-turut sebesar 3.218 ton, 3.983 ton, 3.860 ton, 2.038 ton, 3.331 ton.

2.Berdasarkan perbandingan target pengadaan dan realisasi pengadaan serta perbandingan EOQ dan realisasi pemesanan dapat diketahui bahwa kinerja Perum BULOG Divisi Regional Jawa Timur sebagai penyangga kebutuhan gabah beras dalam negeri tergolong baik namun biaya yang dikeluarkan belum efisien.

\section{Saran}

Berdasarkan simpulan, saran untuk Perum BULOG Divre Jawa Timur adalah hasil EOQ dijadikan bahan pertimbangan dalam menentukan jumlah pengadaan beras sehingga biaya yang dikeluarkan lebih optimal.

\section{DAFTAR PUSTAKA}

BPS.2015. Laju Pertumbuhan Penduduk menurut Provinsi. https:/www.bps.go.id/linkTabelStatis/view /id/1268. Diakses pada tanggal 22 September 2016.

Bulog. 2012. Beras DN dan LN. http://www.bulog.co.id/bisnisberas.php. Diakses pada tanggal 22 September 2016.

Famee, D. A. N. 2015. Efisiensi Persediaan Beras Perum BULOG Divisi Regional Daerah Istimewa Yogyakarta. Program Sarjana Universitas Gadjah Mada, Yogyakarta. (Skripsi Sarjana Pertanian).

Fitriani, N., R. P. Yusuf dan I. K. Rantau. 2014. Analisis persediaan beras di Perusahaan Umum BULOG Divisi Regional Nusa Tenggara Timur.E-Jurnal Agribsisnis dan Agrowisata 3 (1):1-10. 
Heizer, J. dan B. Render. 2008. Manajemen Operasi (Buku 1 Edisi 9). Salemba Empat, Jakarta.

Mahmudi. 2010. Analisis Laporan Keuangan Pemerintah Daerah. STIM YKPN, Yogyakarta.

Petty, W. dan Scott, D. 2005.Financial Management. Prentice Hall, New Jersey.

Raras, Y dan S. A. Casper 2011. Pengaruh penyimpanan terhadap kualitas beras: perubahan sifat kimia selama penyimpanan. Artikel Penelitian Fakultas Teknik Jurusan Teknik Kimia Universitas Diponegoro. eprints.undip.ac.id/36702. Diakses pada tanggal 10 Februari 2017.
Singh, S. dan O. Hensel. 2012. On farm research (OFR) on transplanting paddy: a best bet prototype for drudgery reduction. International Journal of Agriculture 2(4)

Wijayanti, S., S Candra dan $\mathrm{H}$. Sarjono.2011.Analisis persediaan beras nasional dalam memenuhi kebutuhan beras nasional pada Perusahaan Umum BULOG.Jurnal Manajemen, FEB Universitas Bina Nusantara 12 (1):82-96.

Wiranata, R. A.,T. Himawan dan L. P. Astuti. 2013. Identifikasi arthropoda hama dan musuh alami pada gudang beras Perum BULOG dan Gudang gabah mitra kerja di Kabupaten Jember. Jurnal HPT 1(2):52-57. 